\title{
PRACTICAL USE OF CHOSEN RECRUITMENT METHODS IN APPLYING FOR A JOB IN POLAND AND LITHUANIA
}

\author{
Anna Zielińska-Chmielewska ${ }^{1}$, Asta Raupeliene் $\dot{2}^{2}$ \\ ${ }^{1}$ Assist. prof. dr. Poznań University of Economics and Business. Al. Niepodlegtości 10, 61-875 Poznań, Poland, \\ Tel.+48606658890.E-mail address anna.zielinska@ue.poznan.pl \\ ${ }^{2}$ Prof. Dr. Vytautas Magnus University. Universiteto 10, Akademija, Kaunas distr., \\ Lithuania.E-mail address asta.raupeliene@vdu.lt
}

Received 1912 2019; Accepted 09032020

\begin{abstract}
Recruitment is an essential part of the employees' acquisition function of human resource management. It is a base for many practices related to searching, interviewing, hiring and training the new employees. An effective usage of recruitment and selection methods for the company can save time and costs involved in the hiring. A wide literature sources emphasized that the recruitment process is a multitasking and competence required process, especially when the performance of the company is in the scope of the research. This paper examined the recruitment process and selection methods from the aspect of its practical used in Poland and Lithuania. The main objective of this paper was to explore the recruitment and selection methods performance for improving the process of recruitment. The research was carried out trough literature and empirical research based on focus group interview and expert evaluation. Methodology used in the research included statistical techniques of descriptive statistics was performed by STATISTICA program.
\end{abstract}

Key words: applying for a job, selection, recruitment, recruitment techniques

JEL Codes: J21, J24, M5, O15

\section{Introduction}

Human attitude towards work underwent various changes throughout centuries, which was greatly influenced by religion (Jacukowicz, 2004; Oleksyn, 2001; Wajda, 2003). Initially work was despised and considered unbecoming of upper classes. It is worth mentioning that the Protestants had a very positive attitude towards work (Ora et labora) and their diligence, highly developed work ethics and culture significantly contributed to the economic growth. In Europe, people who lived in comfort and prosperity thanks to their work were accepted, but it was inherited wealth and social class that were more valued. However, with the continued development and strengthening of the market economy the number of blue-collar workers increases, as well as the number of hired hands and work started to determine social class and economic prosperity (Beck, 2000; Martin, 2000; Rifkin, 2001).

In the twenty-first century, globalization is a decisive factor affecting the business companies' competitiveness and the struggle for resources. Businesses are looking for new ideas and means to make themselves a difference and become more competitive (Cortinas-Vidal et al., 2014). Scientists (Tamasevicius, et al., 2020; Cortinas-Vidal, et al., 2014; Ding, et al. (2015); and others) mention that the most important asset of any company are their human resource. Cortinas-Vidal, et al. (2014), Guest (2004) and others scientists note, that the business companies should commit to develop the best human resource management practices and to find the new ways to attract the best human capital to have. Therefore, the best companies of the future will be those that attract, engage, develop and retain the most talented employees (O'Leary, et al. 2002). Researchers and practitioners work by developing the effective hiring process and innovative recruitment tools to create competitive advantage for companies.

Copyright (C) 2020. Published by Vytautas Magnus University. This is an open access article distributed under the terms of the Creative Commons Attribution Non-Commercial 4.0 (CC BY-NC 4.0) license, which permits unrestricted use, distribution, and reproduction in any medium provided the original author and source are credited. The material cannot be used for commercial purposes. 
Human resource management is a broad and complex concept, and its reach extends beyond the boundaries of individual entities functioning in the market economy. Any attempt to analyse the most important and most valuable assets of any company - human resource, only on the theory achievements, it is doomed to fail. Hence, the authors' intention is to present universal, timeless, and transnational analyses of the processes involved in human resources management.

The aim of the research is to investigate the recruitment and selection methods, which commonly used by Polish and Lithuanian business companies, and to provide recommendations for the successful application of those methods. The object of the paper - recruitment and selection methods.

The hypothesis are posed that the most commonly used recruitment methods in applying for a job in Poland and in Lithuania may not be selected in terms of suitability and selection of the most proper job candidate. The hypothesis are verified by the application of the results of own researches, reports, expert opinions and the case-studies among job candidates, as well as on domestic and foreign relevant publications on practical use of recruitment and selection methods for applying for a job by a candidate.

The descriptive, comparative, deductive and synthetic analysis methods were broadly used in the research. The results of the analyses were based on the results of own research investigations, reports, expert opinions, as well as on domestic and foreign relevant publications.

\section{Methodology}

The methodology has been prepared to identify the practice of the performance of the recruitment and selection methods in organizations from Poland and Lithuania. The purpose of the research was to provide an empirical evaluation of recruitment and selection methods for business companies, as well as human resource managers (recruiters), and to develop new knowledge about recruitment performance management practice in two countries. The research period from 2010/2011 to 2016/2017 there were involved students from the Poznan University of Economics and Business (Poland) and Aleksandras Stulginskis University (Lithuania). 82 students from the Poznań University of Economics and Business and 44 students from Aleksandras Stulginskis University were involved in the research, which attended the lectures on human resources management every semester each year. The students were divided into 5-people focused groups, which gives 12 teams each year. The students, who have had an experience of participating as the candidates in the recruitment and selection process, were invited to participate in the study. The profile of the sample respondents of this study is shown in the Table 1.

Table 1. Demographic characteristics of respondents $(n=126)$

\begin{tabular}{|c|c|c|}
\hline Gender & $\begin{array}{l}\text { Male } \\
\text { Female }\end{array}$ & $\begin{array}{l}33 \% \\
67 \%\end{array}$ \\
\hline Age & $\begin{array}{l}>19 \\
19-23 \\
24-27 \\
27< \\
\end{array}$ & $\begin{array}{l}2 \% \\
38 \% \\
45 \% \\
14 \% \\
\end{array}$ \\
\hline Education & $\begin{array}{l}\text { Bachelor's } \\
\text { Master's }\end{array}$ & $\begin{array}{l}84 \% \\
16 \%\end{array}$ \\
\hline Employed & $\begin{array}{l}\text { Yes } \\
\text { No }\end{array}$ & $\begin{array}{l}58 \% \\
42 \% \\
\end{array}$ \\
\hline $\begin{array}{l}\text { Employed in the sector } \\
(\mathrm{n}=73)\end{array}$ & $\begin{array}{l}\text { Business } \\
\text { Logistics } \\
\text { Public } \\
\text { Banking } \\
\text { Other }\end{array}$ & $\begin{array}{l}41 \% \\
33 \% \\
10 \% \\
4 \% \\
12 \% \\
\end{array}$ \\
\hline
\end{tabular}


There are more females (67\%) than males (33\%). The majority of the sample, i.e. $(45 \%)$ is $24-$ 27 years old and $38 \%$ are in the age group of $19-23$ years. $84 \%$ of students, participated in the survey were from the bachelor studies and $16 \%$ from the master studies. It was found that the majority of the responders were employed, i.e. $(58 \%)$ and others $(42 \%)$ had no a job at that time. However, they all $(n=126)$ took part in the process of recruitment and selection. Based on the survey results, the majority of the responders had a job in the business companies, i.e. (41\%); accordingly $33 \%$ - in logistics business; $10 \%$ - government owned companies; $4 \%$ - banking service and $12 \%$ - in others sectors (education, service or employed by themselves).

Focus group interviews were carried out in response using a standardized questionnaire. It was emphasized that all surveys were coded and, in that sense, they were anonymous.

The data collected from the questionnaires were processed and analysed, taking into account the following activities:

a) drafting, control and possible correction of questionnaires;

b) input and zero-one coding of data enabling their categorization;

c) carrying out a tabulation, i.e. counting the number of cases belonging to different categories;

d) performing statistical grouping in terms of the type and nature of variables.

Likert scale was applied to measure the effectiveness of different HRM practices. To analyse those data, mean values and standard deviations were calculated. Descriptive statistics of organizational effectiveness, carried out with the STATISTICA program.

\section{Results and discussion}

Human recourse management (HRM) is a system and a philosophy, policy and practices as a whole can influence to the success and performance of the employees work in an organization. A significant of research carried out by Tamasevicius, et al. (2020); Ding, et al. (2015); Amstrong (2008); Chand, et al. (2007); Zheng, et al. (2006); O'Leary, et al. (2002) and others find that human resource management practices are positively related to the organisation performance. Zheng, Morrison, and O'Neill (2006) also claimed that the adoption of good HRM practices can generate better HRM outcomes and contribute positively to firm performance. For better performance, organisations also need to establish and maintain effective human resource management practices, such as recruitment and selection, training and development, employee performance management and reward management (Chand and Katou, 2007). Tamasevicius, et al. (2020), note that HRM practices include training and development, performance appraisal, reward/compensation management, safety and health, recruitment and selection, and industrial relations. Ding, et al. (2015) examined the causal relationships between four different HRM practices: recruitment and selection, reward management, performance management, and induction, training and development - were measured as single-item constructs, which do not reflect the multidimensional nature of these practices. It is not important to identify more or less HRM practice, but we should focus on its integrity and quality.

A wide literature sources emphasized that the recruitment process is a multitasking and competence required process, especially when the goal of the organisation is to increase the job performance. According to Mondy and Noe (2008), recruitment can be defined as the process of attracting people on a timely basis, in sufficient numbers and with appropriate qualifications, to apply for jobs with an organisation. Therefore, recruitment is an essential part of the main function of human resource management that can be defined as the process of creating a pool of candidates interested in a job and choosing the best-qualified ones from within. Based on Human Resources Management ISO/TS 30407 standard, recruitment has been defined as a process of sourcing, attracting, assessing and employing talent for an existing or new position within the organisation (ISO/TS 30407:2017). 
Armstrong (2008), recruitment should fulfil the following three functions: information, motivation and preliminary selection. Selection refers to the process of choosing the individual, from a group of applicants, who is best suited for a particular position and for the organisation (Mondy and Noe, 2008).

According to a literature review, the recruitment and selection processes include an integrated communication process between the organization and the internal or external labour market. The process should be organised in such a way so that it encourages the most talented candidates finding and eliminates those who do not meet the employer requirements.

The success of recruitment process depends on analyses of the most appropriate source for recruitment. This source could be either internal recruitment or external recruitment.

Internal recruitment (from within the organization) involves internal appointment of the employees and often involves personnel retraining so that employees can perform new tasks. There are two options for internal recruitment:

a) open recruitment (open competition) - information about job vacancies is made available to all employees in the organization in the form of internal announcements or closed competition. Each employee who thinks that he or she has the qualifications mentioned in the announcement or in the competition rules may apply for the position.

b) closed recruitment (closed competition) - information about the vacancy is not made available to all employees. A small number of decision-makers decide about the rules, criteria and potential candidates for the job.

It is important to notice that internal recruitment may cause a domino effect in which another vacancy is created (Suchar, 2008), but this method helps to save time and money for organisation and spend less time for new employee socialisation.

Employees can be recruited from outside the company as well. External recruitment involves analysis of the external labour market and attracting candidates. There are two ways of external recruitment:

a) direct recruitment: is carried out by the organization itself with the help of its own recruitment specialists;

b) outsourced recruitment: means using recruitment companies to search for employees. It is often new companies which do not have experience with recruitment process that use services of such companies, as well as organizations which are looking for specialists with rare qualifications or professional aptitude (Armstrong, 2008).

Based on the undergone interviews and case studies under the research purpose, it is important to notice that looking for external employees too frequently is indicative of an improper Human Resource Policy in a company, which may suffer from inefficient employee career development and promotion systems. Looking for external employees is necessary only when highly specialised employees are being sought, there is a need for 'a fresh, young blood' among the crew establish long time ago.

The success of selection process depends on recruiters' competence and practice of using the methods, tools or tests during the selection processes. An effective recruitment and selection methods involved in the searching, interviewing, hiring can save time and costs for the company. The recruitment and selection process has many interlocking parts that are cross-related. Therefore, the consequence of poor quality is a lower return on investment for the recruiting effort and budget, which can be extremely detrimental. The most effective recruiters know what some critical factors that affect the company's recruitment process are, and they strive to improve them. 
In order to reveal the most appropriate set of applicable methods of a candidate for a job in the workplace, the following most popular employee selection techniques were identified in Poland and Lithuania (see Table 2).

Table 2. The characteristics of the most popular selection methods used in Poland and Lithuania

\begin{tabular}{|c|c|c|c|c|c|}
\hline $\begin{array}{l}\text { Selection } \\
\text { method }\end{array}$ & Form & Information & $\begin{array}{l}\text { Presentation of } \\
\text { results }\end{array}$ & $\begin{array}{c}\text { Application and } \\
\text { limitations in } \\
\text { Poland }\end{array}$ & $\begin{array}{c}\text { Application and } \\
\text { limitations in } \\
\text { Lithuania }\end{array}$ \\
\hline \multirow[t]{2}{*}{ Documents } & \multirow[t]{2}{*}{$\begin{array}{l}\text { - standard } \\
\text { personal data } \\
\text { forms } \\
\text { - CV drawn } \\
\text { up by the } \\
\text { candidate }\end{array}$} & \multirow[t]{2}{*}{$\begin{array}{l}\text { - personal details, } \\
\text { education, } \\
\text { acquired } \\
\text { qualifications, } \\
\text { professional } \\
\text { career, hobbies } \\
\text { - candidate's work } \\
\text { expectations } \\
\text { - relevant facts } \\
\text { - professional } \\
\text { career history }\end{array}$} & \multirow[t]{2}{*}{ written pattern } & $\begin{array}{l}\text { - basis for pre- } \\
\text { screening of } \\
\text { applicants } \\
\text { - ease of comparing } \\
\text { candidates if } \\
\text { personal data forms } \\
\text { follow one standard } \\
\text { - basis for } \\
\text { preparing } \\
\text { interviews with } \\
\text { selected candidates }\end{array}$ & $\begin{array}{l}\text { - basis for pre- } \\
\text { screening of } \\
\text { applicants } \\
\text { - ease of comparing } \\
\text { candidates if personal } \\
\text { data forms follow one } \\
\text { standard } \\
\text { - basis for preparing } \\
\text { interviews with } \\
\text { selected candidates }\end{array}$ \\
\hline & & & & $\begin{array}{l}\text { - subjective nature } \\
\text { of information } \\
\text { provided by the } \\
\text { applicant } \\
\text { himself/herself }\end{array}$ & $\begin{array}{l}\text { - information } \\
\text { presented in } \\
\text { abbreviated form, it is } \\
\text { difficult to accurately } \\
\text { assess candidate's } \\
\text { competencies }\end{array}$ \\
\hline \multirow[t]{2}{*}{$\begin{array}{l}\text { Job } \\
\text { interview }\end{array}$} & \multirow[t]{2}{*}{$\begin{array}{l}\text { - interactive } \\
\text { form - } \\
\text { interview with } \\
\text { a candidate } \\
\text { conducted and } \\
\text { led by } \\
\text { employer's } \\
\text { representative }\end{array}$} & \multirow{2}{*}{$\begin{array}{l}\text { - expanding } \\
\text { knowledge about } \\
\text { candidate's } \\
\text { professional } \\
\text { career history } \\
\text { - getting to know } \\
\text { his/her working } \\
\text { style and social } \\
\text { interactions } \\
\text { - relevant facts } \\
\text { - professional } \\
\text { career history }\end{array}$} & \multirow[t]{2}{*}{ - written profile } & $\begin{array}{l}\text { - combined with } \\
\text { the analysis of } \\
\text { documents it may } \\
\text { form a basis for } \\
\text { determining } \\
\text { whether a candidate } \\
\text { will be suitable for } \\
\text { the job }\end{array}$ & $\begin{array}{l}\text { - it allows the } \\
\text { interviewer to convey } \\
\text { a positive image of } \\
\text { the company and } \\
\text { benefit from the } \\
\text { climate of mutual } \\
\text { trust }\end{array}$ \\
\hline & & & & $\begin{array}{l}\text { - assessment is } \\
\text { subjective }\end{array}$ & $\begin{array}{l}\bullet \text { one learns the way } \\
\text { the candidate acts } \\
\text { indirectly by } \\
\text { interpreting his/her } \\
\text { answers }\end{array}$ \\
\hline \multirow[b]{2}{*}{$\begin{array}{l}\text { Group } \\
\text { selection } \\
\text { methods }\end{array}$} & \multirow{2}{*}{$\begin{array}{l}\text { - a group of 6- } \\
12 \text { persons is } \\
\text { working for a } \\
\text { specified } \\
\text { period on a } \\
\text { given task and } \\
\text { observers, } \\
\text { based on } \\
\text { established } \\
\text { criteria, } \\
\text { register and } \\
\text { analysis of } \\
\text { participants' } \\
\text { behaviour }\end{array}$} & \multirow{2}{*}{$\begin{array}{l}\text { - direct } \\
\text { opportunity to } \\
\text { learn how } \\
\text { candidates behave } \\
\text { in work-like } \\
\text { situations both in } \\
\text { terms of social } \\
\text { interactions and } \\
\text { their knowledge } \\
\text { - basic areas of } \\
\text { diagnosis: } \\
\text { interpersonal } \\
\text { skills, } \\
\text { assertiveness, } \\
\text { communication } \\
\text { skills, way of } \\
\text { thinking, attitudes }\end{array}$} & \multirow[t]{2}{*}{$\begin{array}{l}\text { - written analysis } \\
\text { of candidates' } \\
\text { behaviour against } \\
\text { established } \\
\text { criteria }\end{array}$} & $\begin{array}{l}\text { - possibility to } \\
\text { diversify the } \\
\text { assessment of } \\
\text { candidates when } \\
\text { teamwork is of } \\
\text { importance for a } \\
\text { given job }\end{array}$ & $\begin{array}{l}\text { - possibility to } \\
\text { diversify the } \\
\text { assessment of } \\
\text { candidates when } \\
\text { teamwork is of } \\
\text { importance for a } \\
\text { given job }\end{array}$ \\
\hline & & & & $\begin{array}{l}\text { - necessity to } \\
\text { prepare objective } \\
\text { methods for } \\
\text { evaluating and } \\
\text { interpreting } \\
\text { behaviour } \\
\text { - subjects may } \\
\text { oppose to being } \\
\text { socially exposed in } \\
\text { assessment } \\
\text { conditions }\end{array}$ & $\begin{array}{l}\text { - necessity to prepare } \\
\text { objective methods for } \\
\text { evaluating and } \\
\text { interpreting } \\
\text { behaviour } \\
\text { - observers need to } \\
\text { have experience and } \\
\text { knowledge about } \\
\text { group dynamics }\end{array}$ \\
\hline $\begin{array}{l}\text { Career } \\
\text { aptitude tests }\end{array}$ & $\begin{array}{l}\text { - filling in test } \\
\text { forms }\end{array}$ & $\begin{array}{l}\text { - intellectual } \\
\text { potential }\end{array}$ & $\begin{array}{l}\text { - psychological } \\
\text { profile of }\end{array}$ & $\begin{array}{l}\text { - always applied as } \\
\text { one of the elements }\end{array}$ & $\begin{array}{l}\text { - gives insight into } \\
\text { such fields of human }\end{array}$ \\
\hline
\end{tabular}


Anna Zielińska-Chmielewska, Asta Raupeliene

Practical use of Chosen Recruitment Methods in Applying for a Job in Poland and Lithuania

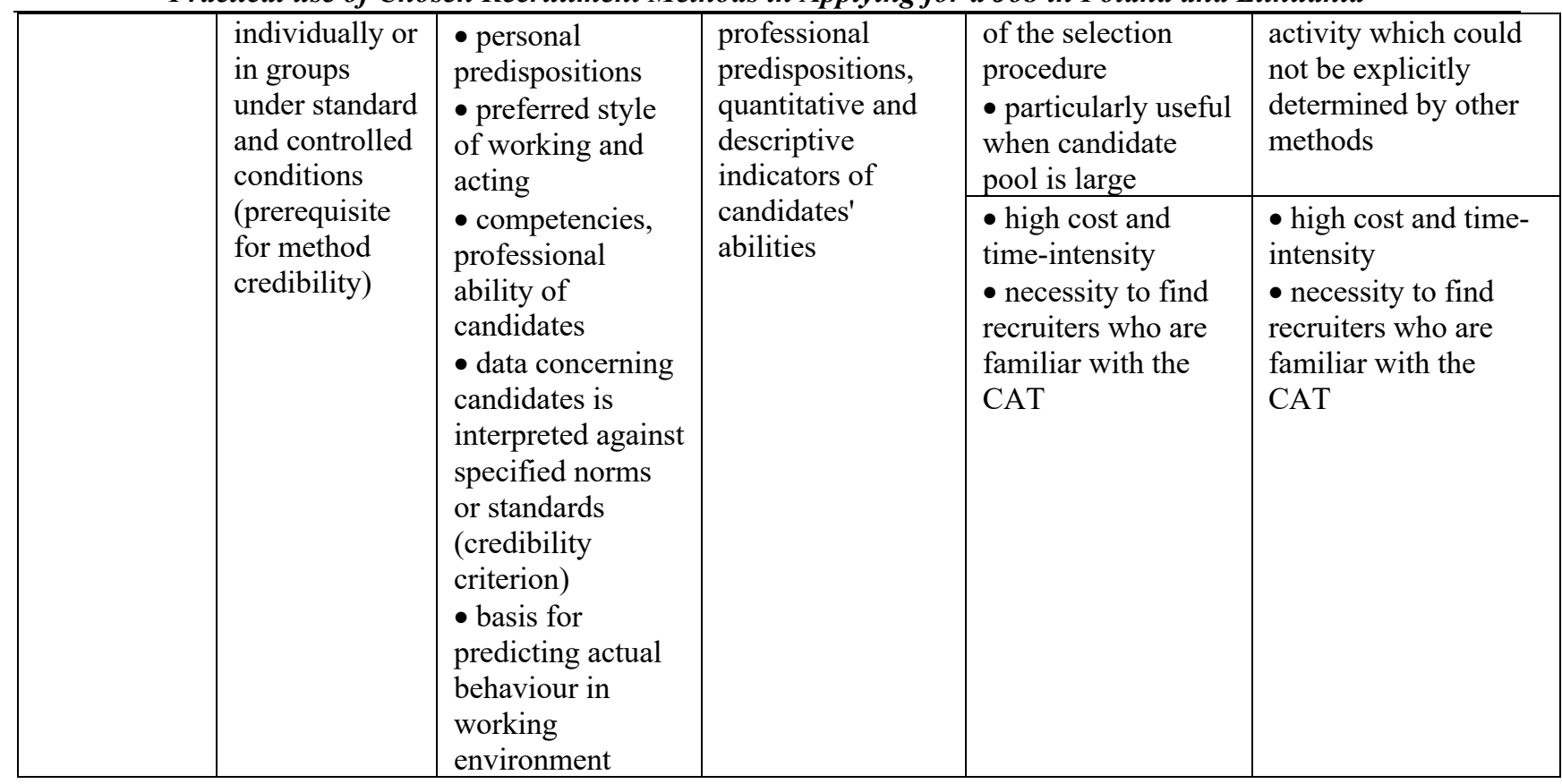

Source: own preparation.

The most effective method of selection was taken by biographical data and behavioural interview. Work samples and ability tests proved to be another most effective method. Slightly lower in the classification was the interview. Personality questionnaires followed by $\mathrm{CV}$ analysis. It can be noticed that personality questionnaires may be a more effective form of selection than the most popular one - CV analysis, but it is worth using them with other methods. The ranking of the selection methods is presented in the Table 3.

Table 3. Frequency and effectiveness of the application of selection methods in practice

\begin{tabular}{|l|r|r|r|}
\hline \multicolumn{1}{|c|}{ Selection method } & $\begin{array}{c}\text { Frequency of application, } \\
\text { \% }\end{array}$ & Mean & $\begin{array}{c}\text { Std. } \\
\text { Deviation }\end{array}$ \\
\hline 1.Standard personal data forms & 92.3 & 4.09 & 1.15 \\
\hline 2.CV drawn up by the candidate & 84.6 & 2.83 & 1.382 \\
\hline 3.Job interview & 97.9 & 4.63 & .338 \\
\hline 4.Group selection methods & 23.3 & 3.01 & 1.18 \\
\hline 5.Career aptitude tests & 59 & 3.84 & .811 \\
\hline 6.Other & 26 & 3.06 & 1.471 \\
\hline
\end{tabular}

Source: own preparation.

Based on the survey results, the most widespread practices in application the selection methods are following: job interview, i.e. (97.9\%); standard data forms (92.3\%); CVs and recommendations $(84.6 \%)$ and career aptitude tests (59\%). The most effective selection methods were identified as a job interview, i.e. (4.63), standard data forms (4.09) and career aptitude tests (3.84). CV drawn up by the candidate were evaluated as the least preferable option with the lowest evaluation score (2.83). The highest agreement between the respondents was reached on the use of job interviews $(0.338)$ and the lowest about the usefulness of CVs and recommendations, i.e. (1.382).

Within the period between 2010/2011 to 2016/2017, after having finished all case studies, all working teams indicated that in order to reply to the results and conclusions of the chosen recruitment methods in applying for a job, following arguments should be taken into account:

1. Before commencing the recruitment process by a company, an analysis of the employment plan should be carried out in order to decide whether job vacancies could be fulfilled within the company. Indeed, in-house recruitment allows to reduce the costs of recruitment, employment, and time spend for introducing new employees to their job duties. 
2. Apart from written documents, job interview is the most important selection technique. Therefore, job interview should not be treated like an ordinary talk due to its distinct features such as: clearly defined roles of the recruiter and respondent, eliciting answers to posed questions, the fact that it is prepared and should not be improvised, and discussing private life details should be limited. On the other hand, it has to be stated that success of a job interview depends on interviewer's skills, in particular on: level of preparedness for a given interview, ability to ask questions and listening skills, ability to create atmosphere conducive to relative openness in communication, familiarity with principles of psychology and skilful avoidance of perception errors, ability to register and interpret interview results as well as ability to formulate assessment in relation to a particular person.

3. It should be noted that in many cases in Poland and Lithuania the recruiters were using information, which was prohibited by legal norms. It turned out that more than 60 percent of job candidates were giving preference to a certain sex, age, marital status or nationality. It is to be underlined that surname may be indicative of one's nationality in employment procedure. Notwithstanding this, such details as address (distance from the place of employment) and age are important criteria considered by employers, although this should not be so.

4. Recruiters should adjust the diversity of the application techniques in accordance to the job's requirements, which should be the main driving force for recruiting an adequate candidate for an adequate free job position. Excessively overwhelmed requirements for the certain job position may lead to a lack of willingness and sense of further search for the free job positions by any candidate.

The most commonly used methods of selection of candidates have been identified during the research in Poland and Lithuania. The main characteristics and peculiarity of the selection methods is presented in the Table 2 .

Students stressed that eye-to-eye contact with a recruiter during a job interview did not always follow the stages described in the literature. There were numerous inaccuracies between the description of the literature and the actual course of the recruitment process stated by job candidates, which mainly consisted of not being prepared to talk to candidates, inaccurate listening, asking similar questions few times in a row, lack of confidentiality of their answers. On the other hand, job candidates appreciated when a recruiter knew their names and surnames because personal contact of an employee to-be with the representative of a higher rank in the enterprise is also recommended. During the job interview a recruiter may elicit substantial information by asking about level of education, field of study, one's major, type of school, mode of education/studies (full time or extramural). One should pay attention to any gaps in education history such as: school name, graduation date, field of study, major/obtained degree. Any inaccuracies in the written application and oral transmission of a job candidate must be clarified.

It is necessary to follow the main stages of job interview process (see Table 4) for the successful selection candidates.

Table 4. The stages of a proper job interview process

\begin{tabular}{|c|c|c|}
\hline $\begin{array}{l}\text { Stage of a job } \\
\text { interview }\end{array}$ & Goals and objectives & Actions \\
\hline $\begin{array}{l}\text { Introduction to } \\
\text { the session }\end{array}$ & $\begin{array}{l}\text { 1. Establishment of goals and meeting } \\
\text { principles } \\
\text { 2. Establishment of relations between } \\
\text { participants } \\
\text { a) breaking the ice and creating friendly } \\
\text { atmosphere } \\
\text { b) creating climate for a substantive and } \\
\text { concrete discussion }\end{array}$ & $\begin{array}{l}\text { 1. Greeting } \\
\text { 2. Introduction of meeting participants } \\
\text { 3. Information about the goal of the meeting, } \\
\text { its duration and interview organization } \\
\text { 4. Presentation of the offer: essential facts } \\
\text { about the company and position for which the } \\
\text { candidate applied } \\
\text { 5. Candidate's questions concerning the job } \\
\text { offer }\end{array}$ \\
\hline $\begin{array}{l}\text { Questions and } \\
\text { candidate's } \\
\text { responses }\end{array}$ & $\begin{array}{l}\text { 1. Clarification of inconsistencies in } \\
\text { candidate's CV. } \\
\text { 2. Providing missing information. } \\
\text { 3. Eliciting information concerning } \\
\text { candidate's professional experience. }\end{array}$ & $\begin{array}{l}\text { Questions referring to: } \\
\text { a) professional career } \\
\text { b) letters of reference } \\
\text { c) knowledge and skills }\end{array}$ \\
\hline
\end{tabular}




\begin{tabular}{|l|l|l|}
\hline & $\begin{array}{l}\text { 4. Verification of candidate's professional } \\
\text { qualifications and assessment of } \\
\text { psychological work aptitude }\end{array}$ & $\begin{array}{l}\text { d) personal views, beliefs and candidate's } \\
\text { preferences }\end{array}$ \\
& $\begin{array}{l}\text { 5. Confirmation of interest in the offer } \\
\text { associated with the offer } \\
\text { 7. Establishing time when a candidate can } \\
\text { commerce work in the new company }\end{array}$ & \\
\hline End of session & $\begin{array}{l}\text { 1. Meeting closure and establishment of } \\
\text { follow-up actions }\end{array}$ & $\begin{array}{l}\text { 1. Summary of the interview } \\
\text { 2. Providing information concerning further } \\
\text { recruitment stages }\end{array}$ \\
\hline
\end{tabular}

Source: own preparation.

The interview process reflects the value and objectives or expectations of the organization places on each candidate. The recruiter can be a good ambassador for the organization by conducting a professional interview and communication.

\section{Conclusions}

In both countries the most common technique used for making a preliminary selection are the written types of application documents, such as: Curriculum Vitae (CV), Motivation Letters (ML) which do not always reflect all possible values, abilities and working skills of a candidate. Resume are commonly used in the French-spoken countries.

From the beginning of the recruitment process relation between recruiter and a candidate should be clearly defined and maintained, which will pay in particular in the case when a recruited candidate is hired.

Any new employee should be introduced to the company's objectives in order to possibly make him/her become employees' objectives. Employees should be involved in the process of defining the organization's objectives, tasks and strategy of their realization.

Moreover, he/she should be informed about the process and the decisions made. Recruiters should adjust the diversity of the application documents depending on specific requirements of a free job position. Throughout the whole analysis period team members claimed that there was no case when a job interview was properly closed, neither summary of the interview was made nor information concerning further recruitment stages for a candidate was provided.

\section{References}

Armstrong M., Cummins A., Hastings S., Wood W. (2008). Wartościowanie stanowisk pracy. Przestrzeganie zasady równej płacy w praktyce [Job evaluation. A Guidebook to Achieving Equal Pay], Oficyna Wolters Kluwer, Warszawa.

Beck U. (2000). The Brave New World of Work, Blackwell, Malden.

Chand M., Katou A. (2007). The Impact of HRM Practices on Organisational Performance in the Indian Hotel Industry. Employee Relations 29 (6): 576-594.

Cortinas-Vidal A., Latorre F. (2014). What job characteristics are preferred by high potential undergraduate students? // Values in shock: the role of contrasting management, economic, and religious paradigms in the workplace [Proceeding of the 14th biennial conference, Riga, Latvia]. Shreveport, LA : International Society for the Study of Work \& Organizational Values, ISBN 9780981799735. p. 186-191.

Ding M. J., Kam, B. H, Zhang J. Y., Jie F. (2015). Effects of human resource management practices on logistics and supply chain competencies - evidence from China logistics service market, International Journal of Production Research, 53:10, p. 2885-2903.

Guest D. (2004). Flexible employment contracts, the psychological contract and employee outcomes: an analysis and review of the evidence. International Journal of Management Reviews, 5(1), 1-19

ISO/TS 30407:2017. Human resource management - Cost-Per-Hire.

Jacukowicz Z. (2004). Kompleksowe zarządzanie pracą [Comprehensive work management], Ośrodek Doradztwa i Doskonalenia Kadr, Gdańsk.

Martin H. P., Schuman H. (2000). Pułapka globalizacji. Atak na demokrację i dobrobyt [Trap of globalization. An attack on democracy and prosperity], Wydawnictwo Dolnośląskie, Wrocław.

Mondy W., and R. Noe. (2008). Human Resource Management. 10th ed. Upper Saddle River, NJ: Prentice-Hall. 
O’Leary B. S., Lindholm M. L., Whitford R. A., Freeman S. E. (2002). Selecting the best and brightest: Leveraging human capital. Human resource management, 41(3), 325-340.

Oleksyn T. (2001). Praca i płaca w zarządzaniu [Work and remuneration in management], Wydawnictwo Międzynarodowej Szkoły Menedżerów, Warszawa.

Rifkin J. (2001). Koniec pracy. Schyłek siły roboczej na świecie i początek ery postrynkowej [End of work. The decline of the world's workforce and the beginning of the post-market era], Wydawnictwo Dolnośląskie, Wrocław.

Suchar M. (2008). Rekrutacja i selekcja [Recruitment and selection], C.H. Beck, Warszawa.

Tamaševičius V., Diskienė, D., Stankevičienė A. (2020). Human resource management practice in Lithuania: evidences and challenges // Montenegrin journal of economics. Podgorica : Economic laboratory transition research. ISSN 1800-5845. eISSN 1800-6698. 2020, vol. 16, no. 1, p. 207-226.

Wajda A. (2003). Praca jako wartość w przekroju historycznym [Work as a value in the historical cross-section] [in:] D. Walczak-Duraj (ed.), Czy zmierzch pracy? [Will work twilight], t. 1, Fundacja Humanizacja Pracy, PłockWarszawa.

Zheng C., Morrison M., O’Neill G. (2006). An Empirical Study of High Performance HRM Practices in Chinese SMEs. The International Journal of Human Resource Management 17 (10): 1772-1803. 